DOI: https://doi.org/10.32839/2304-5809/2019-5-69-92

UDC 378.147:004:811.11

Kornyts'ka Yuliya

National Technical University of Ukraine

"Igor Sikorsky Kyiv Polytechnic Institute"

\title{
WEBQUEST IN ESP CLASSROOM: EFFECT AND STUDENTS' ATTITUDE
}

Summary. Results of recent studies reveal that Web Quest could be a powerful learning environment with a great potential to enhance training quality. Reporting positive evidences of employing WebQuest in language training, the researchers note the close interrelation between learning outcomes and positive acceptance. The current paper aims to test the efficiency of employing WebQuest to develop reading-comprehension skills within ESP curriculum and investigate students' attitude towards it. The participants were fifty students attending the ESP course at the Management and Marketing Department at National Technical University of Ukraine "Igor Sikorsky Kyiv Polytechnic Institute". The experiment lasted sixteen weeks and contained four phases: pretest, implementation, posttest and survey.

Keywords: WebQuest, students' attitude, efficiency, experiment, ESP, reading-comprehension, questionnaire.

Корницька Ю.А.

Національний технічний університет України «Київський політехнічний інститут імені Ігоря Сікорського»

\section{WEBQUEST В КУРСІ АНГЛІЙСЬКОЇ МОВИ ПРОФЕСІЙНОГО СПРЯМУВАННЯ: ЕФЕКТИВНІСТЬ ТА СПРИЙНЯТТЯ СТУДЕНТАМИ}

\begin{abstract}
Анотація. Вміння ефрективно здобувати та опрацьовувати професійно значущу індормацію є важливим критерієм успішної діяльності фахівця в умовах глобалізації світової бізнес спільноти. Оскільки англійська мова все більше зміцнюе позицію мови міжнародної продесійної взаємодії, англомовні інформаційні ресурси розглядаеться як основне джерело отримання актуальної інформації фрахового характеру а навички ефективної роботи з ними сприяють підвищенню рівня професійної компетентності та конкурентоспроможності. Таким чином, однією з ключових складових іншомовної підготовки майбутніх фрахівців $є$ профресійно-орієнтоване читання. Актуальність використання в навчанні професійно-орієнтованого читання нових педагогічних технологій та інноваційних форм роботи, що базуються на ресурсній базі Інтернету, зумовлена їх значним дидактичним потенціалом. Аналіз актуальних досліджень та досвіду практичної реалізації, виявив, що WebQuest може бути потужним навчальним середовищем 3 значним потенціалом для підвищення якості підготовки майбутніх фрахівців. Презентуючи позитивні результати впровадження WebQuest в навчальний процес, дослідники відзначають прямий зв'язок між результатами навчання та позитивним сприйняттям запропонованих видів діяльності. Метою нашого дослідження $€$ перевірка ефективності використання WebQuest в умовах реального навчального процесу для розвитку навичок читання-розуміння в рамках курсу «Англійська мова професійного спрямування» та виявлення ставлення студентів до запропонованого виду діяльності. Учасниками експерименту стали п'ятдесят студентів фракультету Менеджменту и маркетингу Національного технічного університету України «Київський політехнічний інститут ім. Ігоря Сікорського». Експеримент тривав шістнадцять тижнів складав чотири етапи: передекспериментальний зріз, впровадження, постекспериментальний зріз та опитування. Результати експерименту підтвердили дощільність та ефективність використання WebQuest в курсі іноземної мови професійного спрямування.
\end{abstract}

Ключові слова: веб квест, ставлення студентів, ефективність, експеримент, мова професійного спрямування, читання-розуміння, опитування.

Droblem statement. For students specializPing in such dynamic areas as business and economics, reading is one the core skills as they have to absorb massive amounts of professional information in academic settings and throughout their future career. Since English is the global language of business, and it is becoming increasingly true as international relations are expanding, the majority of the topical information is provided in English. Therefore, developing reading skills is one of the main goals in the English classroom.

Theoretical framework. A large body of recent research present the positive effects of Web-based activities for language acquisition. Since World Wide Web grants access to an infinite amount of valid authentic resources, researches consider it as a powerful learning environment, which assists in establishing the connection between learning and real world $[3$, p. $67 ; 7 ; 11]$; has a great potential to enhance coursebooks and tasks in print [5, p. $18 ; 7$, p. 349]; supports crossdiciplinary curriculum [4; 7, p. 223]; facilitates active and situated learning [4; 11]; emphasizes students' centeredness [3, p. 101; 5, p. 36;11].

Having analyzed the studies devoted to the effect of web-based activities in developing reading skills, we are able to note the growing recognition of the Web Quest as the teaching format with the big potential to contribute in training quality owing to:

- valid up-to-date content accessibility [2;6;9];

- ample visual support (graphics, charts, animation, video etc.) [6; 8];

- contextualized language $[1 ; 8 ; 11]$;

- collaborative and individual learning modes $[1 ; 6 ; 9 ; 10] ;$

- learning-by-doing concept $[2 ; 9 ; 11]$.

Unsolved problems under consideration. Reporting positive evidences of employing Web Quest in language training, the researchers note 
the close interrelation between learning outcomes and positive acceptance. Activities accepted as interesting and useful could function as mediators to increase students' motivation, develop and deepen their interest and knowledge. On the contrary, activities that are inconsistent with students' needs, preferences and interests might result in demotivation, increased anxiety and absenteeism.

Since students' preferences for training activities are associated with motivation factors and have a direct bearing on the learning outcomes, choices in training are to be influenced by students' perceptions and considered in this context.

The study aims to examine students' reading-comprehension skills after employing WebQuest and investigate students' attitudes toward it.

Paper main body. To test the efficiency of employing Web Quest within ESP curriculum and investigate students' attitude towards it we conducted an experiment where we compared learning outcomes in experimental and control groups and collected data regarding students' evaluation.

The research instruments include: the pretest and posttest and questionnaire. All instruments for data collection were specially developed for the study, checked and approved. The test were created based on Cambridge English: Business Vantage, which is equal to Common European Framework Reference at B2 level. The test contained five blocks of tasks assessing:

1) lexical comprehension;

2) literal comprehension;

3) interpretive comprehension;

4) applied comprehension;

5) affective comprehension.

For the WebQuest tasks, the material was selected, checked and approved to ensure its compliance with the curricula.

The questionnaire was used to collect data on the students' attitude at the end of the experimental period. The questionnaire contained 7 statements dealt with the evaluation of the reading course component and 1 open-ended question. The participants were offered to use a five point Likert scale and an alternative variant "I cannot evaluate".
Tests and questionnaire were delivered online. Obtained data was processed by means of the statistical analysis software.

The experiment lasted 16 weeks. At the beginning of the experimental period (week 1) the participants took a pretest. Since, the results in both groups were approximately equal we randomly designated the academic groups as control (A) and experimental (B). The control group (A) received routine reading tasks set in accordance with the curriculum. The experimental group (B) was offered Web Quests instead. The participants from group B were provided with the explanation part - introduced the objectives and instructions before treatment.

At the end of the experimental period, the posttest was delivered to collect data on participants' progress both for group A and group B and the questionnaire to obtain data on the students' evaluation of the reading course component.

The questionnaire and tests were administrated online. A response rate was $100 \%$ (considered as an acceptable result to obtain valid data). SSP software was used to analyze data collected from the tests and questionaries, data collected from open-ended questions was processed by means of Nvivo.

Learning achievements.

Tables 1 and 2 present the overall results of preand posttests for group A and Group B and enables the comparison of the progress achieved by both groups.

As it can be seen, the average scores of posttest are higher than pretest for both groups, but Group B reported more significant raise ( 70.45 vs 80.3 ).

The average score of each section in the posttest is also higher than in the pretest and the positive evidence of Group's B progrees is clearly seen.

The obtained results indicate that WebQuest may be accepted and employed on a regular basis as it has proved to be effective training tool.

Students' attitude.

The analyzed data revealed that the grand mean of the participants in Group B considered reading component of the course as interesting and motivating while the majority of Group A representatives demonstrated lower level of enthusiasm.

The highest and lowest scores (pre- and posttests for group A and Group B)

\begin{tabular}{|l|c|c|c|c|}
\hline & $\begin{array}{c}\text { Group A } \\
\text { Pretest }\end{array}$ & $\begin{array}{c}\text { Group A } \\
\text { Posttest }\end{array}$ & $\begin{array}{c}\text { Group B } \\
\text { Pretest }\end{array}$ & $\begin{array}{c}\text { Group B } \\
\text { Posttest }\end{array}$ \\
\hline The highest score & 7.3 & 8.3 & 7.2 & 9.1 \\
\hline The lowest score & 6.1 & 6.6 & 6.4 & 7.4 \\
\hline The average score & 6.75 & 7.45 & 6.78 & 8.3 \\
\hline
\end{tabular}

Source: author's development

The average scores for test sections (pre- and posttests for group A and Group B)

\begin{tabular}{|l|c|c|c|c|}
\hline & $\begin{array}{c}\text { Group A } \\
\text { Pretest } \\
\text { Average results }\end{array}$ & $\begin{array}{c}\text { Group A } \\
\text { Posttest } \\
\text { Average results }\end{array}$ & $\begin{array}{c}\text { Group B } \\
\text { Pretest } \\
\text { Average results }\end{array}$ & $\begin{array}{c}\text { Group B } \\
\text { Posttest } \\
\text { Average results }\end{array}$ \\
\hline 1) lexical comprehension & 6.4 & 6.9 & 6.5 & 7.8 \\
\hline 2) literal comprehension & 6.7 & 7.4 & 6.6 & 7.9 \\
\hline 3) interpretive comprehension & 7.1 & 7.8 & 6.9 & 8.5 \\
\hline 4) applied comprehension & 6.6 & 7.3 & 6.8 & 8.4 \\
\hline 5) affective comprehension & 6.9 & 7.6 & 7.1 & 8.8 \\
\hline \multicolumn{1}{|c|}{ Average score } & $\mathbf{6 . 7 5}$ & $\mathbf{7 . 4 5}$ & $\mathbf{6 . 7 8}$ & $\mathbf{8 . 3}$ \\
\hline
\end{tabular}




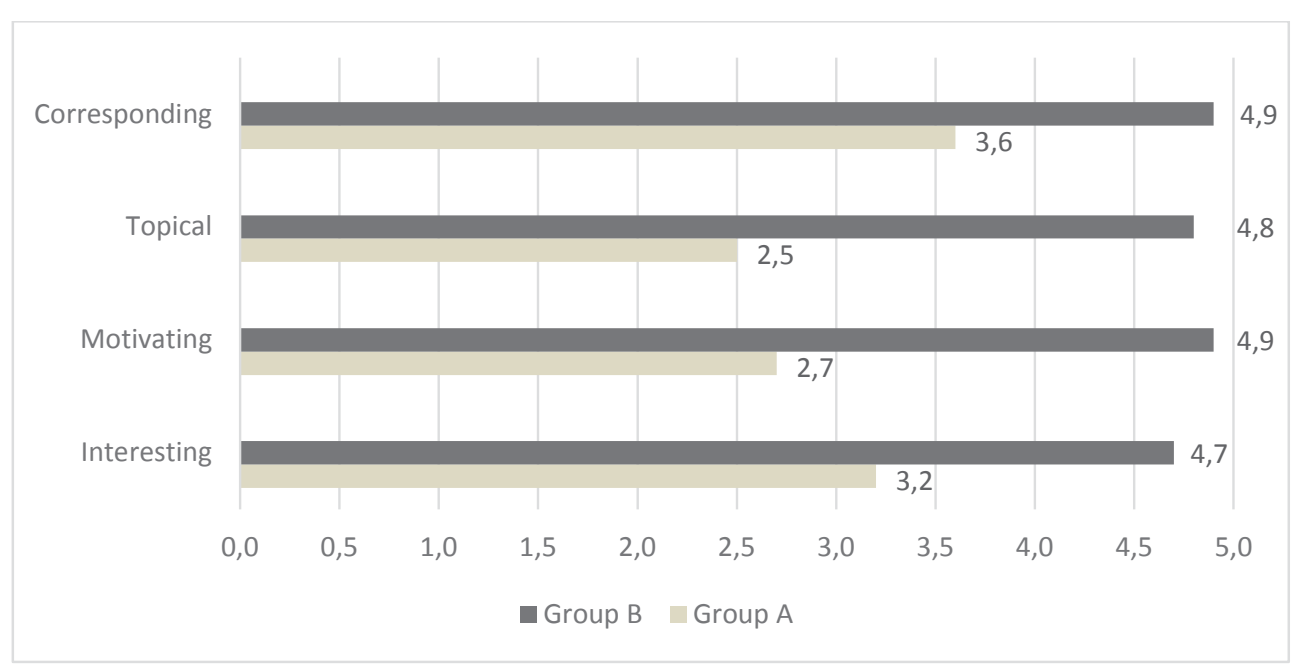

Figure 1. Average rating for statements 1-4

Source: author's development

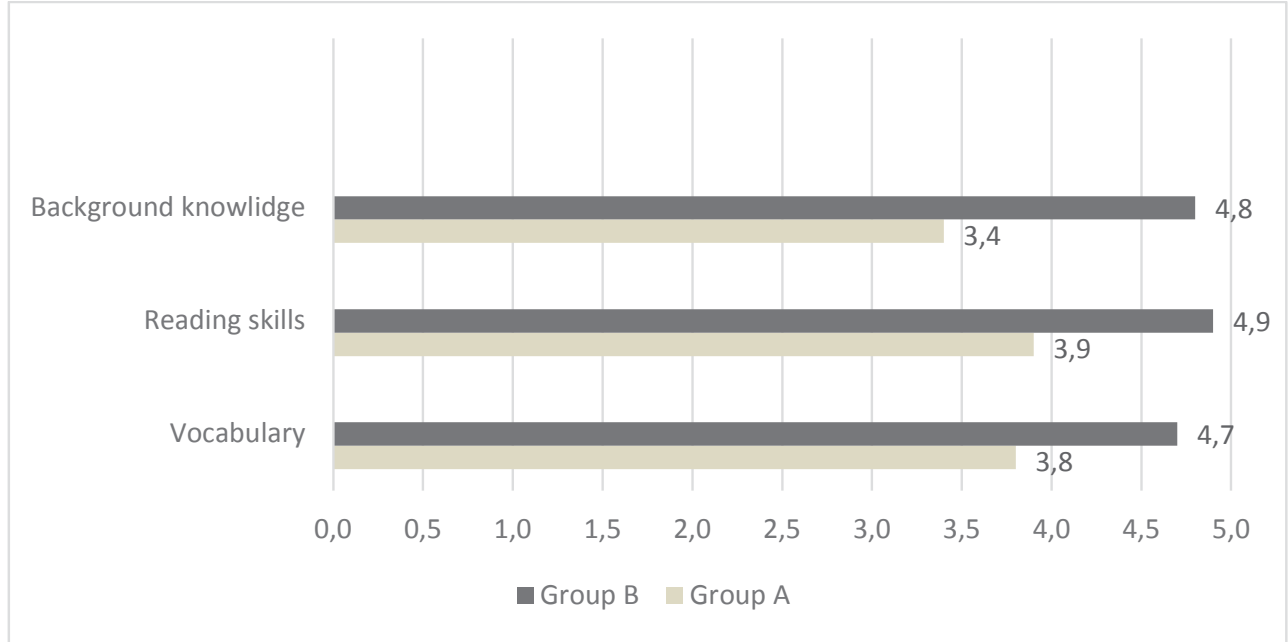

Figure 2. Average rating for statements 5-7

Source: author's development

The majority of participants in Group A were not satisfied with the topicality and correspondences to the speciality-training curriculum. Participants from group B rated the same categories more positively. The visual representation of the obtained results are presented below (figure 1).

In terms of evaluating the progress in reading skills, the participants from group A were rather neutral while Group B rated the course as more effective. As an assistive option for building their background knowledge, the representatives of the group B considered the reading course component more useful. Tasks were less rewarding for enriching vocabulary for the participants in a Group A.

The open-ended question was "How do you feel about reading component of the course". The responses of the participants from Group A demonstrating low level of satisfaction comprised $64 \%$ and were rather similar on sense: the materials were 1) outdated, 2) not rich in references for fur- ther learning, 3) proposed in a printed format, which was not always convenient to work with. Neutral responses were provided by $24 \%$ and $12 \%$ would like to have a wider choice of topical material.

The responses of Group B were more positive. The participants reported the high-level satisfaction and appreciated the opportunity to try new format of learning. No negative responses or complaints were indicated.

Conclusions. The study showed that WebQuest could be an effective tool for facilitating the process of developing reading-comprehension skills in the ESP classroom. It is compatible with the regular curriculum and has a good potential to reform the traditional reading component of the ESP course and make it more topical and motivating. However, the process of implementing new formats of training requires not only careful planning, but also monitoring the students' feedback. 


\section{References:}

1. Burchum, J.L.R., Russell, C.K., Likes, W., Adymy, C., Britt, T., Driscoll, C., Graff, J.C., Jacob, S.R. \& Cowan, P.A. (2007). Confronting challenges in online teaching: The WebQuest solution. MERLOT Journal of Online Learning and Teaching, 3, 40-57.

2. Dodge, B. (1997). Some thoughts about webquests. Retrieved from: http://webquest.org/sdsu/about_webquests.html

3. Dudeney, G. (2007). The Internet and the Language Classroom (2nd ed.). United Kingdom : Cambridge University Press.

4. M. Eady, L. Lockyer (2013). Tools for learning: technology and teaching strategies. Retrieved March 23, 2019, from: https://ro.uow.edu.au/cgi/viewcontent.cgi?referer=https://www.google.com/\&httpsredir=1\&article=1413\& context=asdpapers;Tools

5. Eastment, D. (2015). The Internet and ELT: The Impact of the Internet on English Language Teaching (2nd ed.). UK : Steel Balls Pr.

6. Irzawati, I. \& Asiah, N. (2013). Using webquest in learning grammar: students' perceptions in higher education. Advances in Language and Literary Studies. Vol. 4, No. 1; January 2013.

7. Krajka, J. (2007). English Language Teaching in the Internet-Assisted Environment. Issues in the Use of the Web as a Teaching Medium. Lublin: Maria Curie-Skłodowska University Press.

8. March, T. (2003). The Learning Power of WebQuests. Educational leadership, New Needs, New Curriculum (61), $42-47$.

9. M. Megala, P. Madhumathi (2016). Enhancing Reading Skill through WebQuest in Collaborative Learning Environment. Retrieved April 16, 2019, from https://pdfs.semanticscholar.org/b48c/2dcf9bc836e4285ef 75d8760a6c70c729206.pdf

10. Murray, D. \& McPherson, P. (2004). Using the web to support language learning. Sydney, Australia : National Centre for English Language Teaching and Research.

11. Sorcia, H., Ramírez-Romero, J., Acuña, M. (2017). WebQuests in EFL Courses: A New Look for a Classic Activity. Retrieved May 5, 2019, from: https://www.mextesol.net/journal/index.php?page=journal\&id_article=2077 